\title{
Dental Biofilm and Saliva Biochemical Composition Changes in Young Orthodontic Patients
}

\author{
Shady Ahmed Moussa ${ }^{1 *}$, Hany Gameil Gobran², Mohamed Ahmed Salem ${ }^{3}$ and Ibrahim Farouk \\ Barkat $^{4}$
}

${ }^{1} D D S$, MRACDS (DPH), Lecture in Pediatric Dentistry and Oral Health, Zagazig University, Egypt, Consultant of Pediatric Dentistry and Dental Public Health (PHCC, Qatar)

${ }^{2}$ DDS, Lecture in Oral and Dental Biology, Al-Azhar University, Faculty of Dentistry, Cairo, Egypt

${ }^{3}$ DDS, Lecture in Orthodontic, Al-Azhar University, Faculty of Dentistry, Assuit, Egypt

${ }^{4}$ DDS, Lecture in Pediatric Dentistry and Oral Health, Al-Azhar University, Faculty of Dentistry, Cairo, Egypt

Received: February, 14, 2017; Accepted: February 20, 2017; Published: February 28, 2017

*Corresponding author: Shady Ahmed Moussa,Lecture in Pediatric Dentistry and Oral Health, Zagazig University, Egypt/Consultant of Pediatric Dentistry and Dental Public Health (PHCC, Qatar), P.0. 26555;Email: shashyshaty@yahoo.com

\begin{abstract}
Saliva and dental biofilm of children with orthodontic treatment may be associated with high risk factors that increase incidence of caries development in this population.

Aim:To assess the dental biofilm and saliva biochemical composition of young fixed orthodontic patients.

Design:The sample comprised 64 participants between 12 to 18 years of age, of whom 32 had fixed orthodontic treatment as study group and 32 did not as a control group. Supragingival biofilm samples were collected from all teeth of all participants by using sterile curettes. The level of insoluble extracellular polysaccharide (IEPS)Calcium (Ca), and phosphorus (Pi) concentrations in dental biofilm was measured using phenol sulphuric acid colorimetric method. The estimated unstimulated salivary flow, $\mathrm{pH}$, buffering capacity and count of Streptococcal Mutants were determined on selective media of all participants.
\end{abstract}

Results:Dental biofilm Ca, and Pi concentration did not differ between both groups but the dental biofilm of orthodontic patients showed higher IEPS levels parallel with high salivary count of S. Mutans. However, there were lowering in $\mathrm{pH}$ and buffering capacity than others without orthodontic treatment $(P<0.05)$.

Conclusions:The saliva and dental biofilm of fixed orthodontic patients have higher cariogenic incidence than who are without orthodontic appliances.

\section{Introduction}

Enamel smooth surfaces demineralization, usually is unfortunately a common complication that range from 2-96\% of orthodontic patients [1]. This variation arises as a result of different methods used to assess and score the presence of decalcification [2]. However, the teeth most commonly affected are maxillary lateral incisors, maxillary canines and mandibularpremolars [3]. Another study revealed that, any tooth in the mouth can be affected, and often a number of anterior teeth show decalcification. Whilst the surface demineralizion remains intact, there is a possibility of demineralization of the lesion. In severe cases, frank cavitation is seen which requires restorative intervention. Half of children treated with fixed orthodontic appliances had at least one white spot after treatment; maxillary lateral incisors are most commonly affected site [4]. The incidence or number of white spot formations did not in proportional to the length of treatment, although many studies $[5,6]$ found that rapidly demineralization can occur within thefirst month of fixed orthodontic appliance treatment. This has focused on aesthetic implications and the need for the rate of caries assessment before treatment. On the other hand, there was no incidence of white spot formation associated with lingual bonded retainers, which would suggest flow rate and salivary buffering capacity, have an important role in surface protection against acid attack [4]. Some authors concluded that, the biochemical of saliva and dental biofilm contribute significantly to interact between the oral environment and the mineral tissue of the teeth. Saliva is an exocrine secretion with $99 \%$ water and a variety of proteins and electrolytes including sodium, potassium, Calcium, chlorine, magnesium, bicarbonate, and phosphorus. The main functions of saliva include protecting and cleaning the mouth, also to maintain the $\mathrm{pH}$ and integrity of hard and soft tissues in the oral cavity [7]. The analysis of organic and inorganic composition of saliva may contribute to the evaluation of caries incidence and to diagnose of other associated diseases [8]. Cariogenicity of the dental biofilm depend on electrolytes level such as fluoride, calcium, and phosphorus, may also be associated with caries incidence increase if its Insoluble extracellular polysaccharide content is low $[9,10]$. Insoluble extracellular polysaccharide plays an important role in bacterial adhesion; the Insoluble extracellular polysaccharide on cell walls of the bacteria also increases biofilm thickness, resulting in increased acid formation at the tooth 
biofilm interface [11]. This study was conducted to evaluate the changes in biochemical composition of dental biofilm and saliva in fixed orthodontic young patients.

\section{Material And Methods}

According to world medical association declaration of Helsinki [12], study population and ethical local institutional approval for study sample comprised 64 participants between 12 to 18 years-old. The study group was composed of 32 patients scheduled for fixed orthodontic treatment at the department of orthodontics, (Al-Azhar University, Assuit, Egypt), and the control group consisted of 32 patients without any orthodontic treatment. Patients with debilitating diseases, that were under current treatment with drugs, that were users of mouth wash, that had dental prosthesis or inability to provide a saliva sample due to lack of cooperation or difficulty expectorating were excluded from the study. All parents or legal guardians received adequate information and written consent for collection of dental biofilm and saliva samples from participants.

\section{Dental biofilm samples}

Prior collection of samples, patients were asked to stop oral hygiene measures for 24 hour, which was performed on other day from the clinical examination. Supragingival biofilm samples were collected from all teeth by using sterile curettes and stored at $-20^{\circ} \mathrm{C}$ for analysis [13]. For 24 hours, dental biofilm samples were vacuum-dried over phosphorus pentoxide [14]. After dissection dry weight of samples were measured using an analytical balance. For $\mathrm{Ca}$, and Pi extraction, $0.5 \mathrm{ml}$ of hcl was added to the microtube in the proportion of $0.1 \mathrm{ml} / \mathrm{mg}$ dry weight biofilm. At room temperature, after 3 hour and under constant agitation, an equal volume of total ionic strength adjustment buffer II, modified with $20 \mathrm{~g}$ naoh/L, pH 5.0 was added to the microtube. For $10 \mathrm{~min}$, the samples were centrifuged at 11,000g, and the supernatant was retained for measuring of the $\mathrm{Ca}$, and $\mathrm{Pi}$ concentrations. Ca, Pi level were measured by using (ELI TECH kit), processed in microlab analyzer spictrophoton (Microlab 300 ). $1 \mathrm{M}$ naoh was added to the remaining precipitate after washing by saline in the proportion of each $0.2 \mathrm{ml} / \mathrm{mg}$ dry weight biofilm. For 3 hours, samples were agitated and then centrifuged. Supernatant was removed for measuring Insoluble extracellular polysaccharide (IEPS) levels that were determined by colorimetric phenol sulphuric acid method $[15,16]$.

\section{Salivary flow rate}

At least 2 hours after eating and oral hygiene measures in order to minimize the effects of diurnal variability in salivary composition [17]. Unstimulated saliva samples collected from all the groups by spitting into a preweighed tube during an one min period which was weighed again, and the unstimulated flow rate calculated.

\section{Streptococcal Mutans Count(S. Mutans)}

About $3 \mathrm{ml}$ from saliva samples which collected were stored in a sterile calibrated universal container that were divided into two separate parts of samples, one of them inoculated onto MitisSalivarius agar media (Becton Dickinson and DIFCO Company, Chicago, USA)was used for isolation S. Mutans that is the selective medium [18] mitisSalivarius agar media contents: (Pancreatic digest of casein 6gm, Proteose peptone 9gm, Proteose peptone 5gm, Saccharose 50gm, Dextrose 1gm, Dipotassium phosphate 4gm, Trypan blue 0.075gm, Crystal violet 0.008gm and Agar 15gm) after the samples were taken. The medium was prepared according the manufacturing instructions as: $90 \mathrm{gm}$ of the medium and $150 \mathrm{gm}$ sucrose were dissolved in 1liter of distilled water by heating. The dissolved components were autoclaved at $121^{\circ} \mathrm{C}$ for 15 minutes and left to cool to $45-50^{\circ} \mathrm{C}$ and just prior to pouring, $1 \mathrm{ml}$ of $1 \%$ sterilized potassium tellurite and $1 \mathrm{ml}$ of 200 units $/ \mathrm{ml}$ sterilized Bacitracin were added. Sterilization of Potassium Tellurite and Bacitracin was performed by filtration through millipores bacterial filters. About $20 \mathrm{ml}$ of the medium was poured in each Petri plate, all allowed to solidify at room temperature and then stored in the refrigerator at $4^{\mathbf{o}_{\mathrm{C}}} \mathrm{C}$ for no more than four weeks. Identification of oral S. Mutans was confirmed by biochemical tests like mannitol and sorbitol fermentation and catalase [19] colony counting was done with a magnifying glass and the count of S. Mutans was expressed as the number of colony forming units per milliliter $(\mathrm{cfu} / \mathrm{ml})$ of saliva. Semiquantitation of the number of colonies was done by multiplying the actual colony count with $1 \times 10^{5}$ because of the part that the saliva sample was diluted one thousand times 1:5 dilution $[20,21]$.

\section{Salivary pH and buffering capacity}

Other part of saliva samples used to measure salivary $\mathrm{pH}$ by using pH meter [22] (pH18 Aqua Lytic Co., USA).Buffering capacity is determined by quantitative test using a handheld. This method involves the addition of $0.5 \mathrm{ml}$ of saliva to $1.5 \mathrm{ml}$ of $5 \mathrm{M}$ Hcl. Mixture was vigorously shaken. Then stream of Nitrogen was passed through the mixture for 20 minutes to eliminate carbon dioxide from the sample and allowed to stand for $10 \mathrm{~min}$ when the final $\mathrm{pH}$ is measured [23].

\section{Results}

Data were checked entered and analyzed by using SPSS (version 22). Data were presented as mean and Standard Deviation (SD) or quantitative variable. Student's t-test was used for composition of two means $(P<0.05)$ was considered statistically significant. Normality was tested using the Shapiro-Wilk test. (Table 1) shows the characteristics of study participants. No group differences were found in participant age and sex $(P>0.05)$. Since no statistically significant differences were found between sex and age so that, data were combined for them. (Table 2) shows nonmicrobialbiofim concentration of $\mathrm{Ca}$, Pi and salivary flow rate $(P>0.05)$. These values did not differ between the two groups. Salivary $\mathrm{pH}$ and buffering capacity were, however, significantly lower in Salivary samples obtained from study group $(P<0.05)$. Additionally, IEPS concentrations were significantly higher $(P<0.05)$ and S.Mutans colonies count $(P<0.001)$ in study group. 
Table 1: Shows the mean values, standard deviations and the statistical analysis of for sex and age.

\begin{tabular}{|c|c|c|c|c|c|}
\hline Variable & \multicolumn{2}{|c|}{$\begin{array}{c}\text { Study group } \\
\text { n: 32 }\end{array}$} & \multicolumn{2}{c|}{$\begin{array}{c}\text { Control Group } \\
\text { n: } \mathbf{3 2}\end{array}$} & P Value \\
\hline Age & \multicolumn{2}{|c|}{$16.4 \pm 1.4$} & \multicolumn{2}{|c|}{$15.8 \pm 1.6$} & 0.09 NS \\
\hline Sex & n. & $\%$ & n. & $\%$ & \\
Male & 14 & $43.75 \%$ & 11 & $34.375 \%$ & 0.44 NS \\
Female & 18 & $56.25 \%$ & 21 & $65.625 \%$ & \\
\hline
\end{tabular}

Significant differences $(p<0.05) *$

Insignificant differences $(p>0.05)$ NS

Sample size calculation: done at 80 power and $95 \% \mathrm{Cl}$ the estimated

sample is 64 participate 32 in each group using open Epi, (version 2).

Table 2: shows the mean values, standard deviations range and the statistical analysis of the oral variables.

\begin{tabular}{|c|c|c|c|}
\hline Variable & $\begin{array}{l}\text { Study group } \\
\text { n: } 32\end{array}$ & $\begin{array}{l}\text { Control Group } \\
n: 32\end{array}$ & p Value \\
\hline $\begin{array}{c}\text { Calcium (Ca) } \mathrm{mg} / \mathrm{dl} \\
\text { Range }\end{array}$ & $\begin{array}{c}14.1 \pm 1.2 \\
(10.77)-(17.1)\end{array}$ & $\begin{array}{c}14.1 \pm 1.75 \\
(11.1)-(19.3)\end{array}$ & 0.91 NS \\
\hline $\begin{array}{c}\text { Phosphorus (Pi) } \\
\text { mg/dl } \\
\text { Range }\end{array}$ & $\begin{array}{c}27.4 \pm 2.6 \\
(19.15)-(31.4)\end{array}$ & $\begin{array}{c}26.2 \pm 3.6 \\
(22.06)-(34.21)\end{array}$ & $0.12^{\mathrm{NS}}$ \\
\hline $\begin{array}{l}\text { (EPS) lg EPS/mg } \\
\text { Range }\end{array}$ & $\begin{array}{c}187.1 \pm 60.9 \\
(118.92)-(327.8)\end{array}$ & $\begin{array}{c}155 \pm 67.1 \\
(101.19)-(331.23)\end{array}$ & $<0.05^{*}$ \\
\hline $\begin{array}{c}\mathrm{pH} \\
\text { Range }\end{array}$ & $\begin{array}{c}6.1 \pm 0.3 \\
(5.6)-(6.8)\end{array}$ & $\begin{array}{c}6.5 \pm 0.46 \\
(5.54)-(7.14)\end{array}$ & $<0.05^{*}$ \\
\hline $\begin{array}{l}\text { Buffering capacity } \\
\text { Range }\end{array}$ & $\begin{array}{c}2.114 \pm 0.184 \\
(1.9)-(2.56)\end{array}$ & $\begin{array}{c}2.365 \pm 0.248 \\
(1.98)-(2.8)\end{array}$ & $<0.05^{*}$ \\
\hline $\begin{array}{c}\text { Unstimulated } \\
\text { Salivary flow rate } \\
\text { Range }\end{array}$ & $\begin{array}{c}0.693 \pm 0.005 \\
(0.604)-(0.791)\end{array}$ & $\begin{array}{c}0.694 \pm 0.04 \\
(0.628)-(0.776)\end{array}$ & $0.94^{\mathrm{NS}}$ \\
\hline $\begin{array}{c}\text { St. mutans }(\mathrm{cfu} / \mathrm{ml}) \\
\times 10^{5} / \mathrm{ml} \\
\text { Range }\end{array}$ & $\begin{array}{c}2.02 \pm 0.46 \\
(1.337)-(2.767)\end{array}$ & $\begin{array}{c}1.4 \pm 0.5 \\
(0.604)-(1.984)\end{array}$ & $<0.001^{* *}$ \\
\hline
\end{tabular}

Significant differences $(P<0.05)$ *

Highly significant differences $(P<0.001) * *$

Insignificant differences $(p>0.05)$ NS

\section{Discussion}

Saliva has an important role in caries development due to many factors such as it participates in the dilution of substances intra oral cavity, mechanical cleaning, post-eruptive maturation, enamel dental remineralization and demineralization, pellicle formation, antimicrobial action and buffering action produced by biofilm and foods $[24,25,26,27]$. Many studies have been conducted to investigate the changes of microbial environment in patients undergoing fixed orthodontic treatment [28,29,30]. On the other view, a few previous researches designed to evaluate changing salivary nonmicrobial composition of orthodontic patients [31,32]. The saliva of fixed orthodontic appliances patients had lower $\mathrm{pH}$, buffering capacity and calcium concentration than that of patients without it. These oral changes are enough to cause tooth demineralization [23]. The saliva buffering capacity, defined as salivary resistance to change in $\mathrm{pH}$, is assigned to carbonate bicarbonate systems, phosphates and proteins $[33,34]$. The bicarbonate system is responsible for about
$85 \%$ of the buffering capacity in the $\mathrm{pH}$ range of 7.2 to 6.8 . When the salivary flow rate increases, the concentration of bicarbonate ions also increases $[35,36,37]$. Another study revealed that, saliva with low calcium concentration has a lower $\mathrm{pH}$ and, therefore, a greater susceptibility to demineralization than others who have higher concentrations of calcium [25]. Some investigators reported that the salivary calcium concentration is highly dependent on salivary flow rate and $\mathrm{pH}$, so that, the moreincrease in the salivary flow rate the more increase in the calcium ions concentration of saliva [38]. However, some other authors have found that the concentration of calcium ions decreases as salivary flow rates increase [37,39]. Our finding revealed that, there was insignificant correlation between calcium ion concentration and salivary flow rate or between salivary flow rate and buffering capacity. Some others found $[40,41,42]$ an increase in the salivary flow rate of fixed orthodontic appliances patients. Laine and Pienihakkinen [43] concluded that, the difference was insignificant between these two variables and also did not find any correlation. Positive correlation between salivary flow rate and buffering capacity has been reported by others $[26,44]$. These finding were in disagreement with the result of the present study, since an insignificant correlation between both groups studied was found.This variation arises as findings attributed to different methods used to assess and determine levels of these variables. Teixeira et al, [24] reported that, there was a significant decrease in salivary buffering capacity and $\mathrm{pH}$ whose may be lead to tooth demineralization in patients using orthodontic appliances that support direct relation between $\mathrm{pH}$ and buffering capacity of saliva in decreases and increased risk of caries. These previous findings were parallel to our results and agreement with result of Kanaya et al, [41] results. Therefore, in present study, there was significant increase of IEPS through study group; Mattos-Granner et al, [45] showed that IEPS producing ability of cariogenic microorganisms may play a greater role in development of caries rather than the number of microorganisms present. In other word, the higher concentrations of IEPS the more cariogenicity [46]. Sucrose rich diets are strongly correlated with IEPS production in dental biofilm, and increase cariogenic bacteria, in turn, associated with a greater ability to produce IEPS [11]. According to Opaloglu-Ak et al., [47] long term utilization of orthodontic appliances may have a negative effect on microbial flora and increase the risk of new carious lesions. Moreover, Maret et al., [48] showed that oral microflora changed with time in the orthodontic patients group compared to the control group, in S. Mutans and Lactobacillus, numbers increased during the 6 months of follow-up in their study and these results concur present study findings positively.

\section{Conclusion}

Although, our finding revealed that the biochemical composition being similar between both groups, the caries risk factors were altered in the orthodontic patients So that the effective preventive measures, oral hygiene measures, diet counseling, prophylaxis and topical fluoride application should be applied for orthodontic patients to control increasing in biofilm cariogenicity which reflect on the prevalence of caries. 


\section{Why This Paper Is Important In Dentistry Field?}

Dentists should be aware that most of orthodontic appliances patients from children and adolescents who have oral environment with higher cariogenic potential than who are without appliances. Therefore, supervision for restricted oral hygiene measures by parents or guardians is fundamental for effective control and the prevention of dental caries in orthodontics patients.

\section{References}

1. Chang HS, Walsh LJ, Freer TJ. Enamel demineralization during orthodontic treatment. Aetiology and prevention. Aus Dent J. 1997;42(5):322-327. doi: 10.1111/j.1834-7819.1997.tb00138.x

2. Mitchell L. Decalcification during orthodontic treatment with fixed appliances,An overview.Br J Orthod. 1992;19(3):199-205.

3. Geiger AM, Gorelick L, Gwinnett AJ, Griswold PG. The effect of a fluoride program on white spot formation during orthodontic treatment. Am Orthod Dento Orthop. 1988;93(1):29-37.

4. Gorelick L, Geiger AM, Gwinnett AJ. Incidence of white spot formation after bonding and banding. Am J Orthod. 1982;81(2):93-98.

5. O'Reilly MM, Featherstone JD. Demineralisation and remineralisation around orthodontic appliances, in vivo study. Am J Orthod Dento Orthop. 1987;92(1):33-40.

6. Oggard B, Rolla G, Arends J. Orthodontic appliances and ename demineralisation. Part 1. Lesion development. Am J Orthod Dento Orthop. 1988;94(1):68-73. doi.org/10.1016/0889-5406(88)90453-2

7. IEPStein JB, Scully C. The role of saliva in oral health and the causes and effects of xerostomia. J Can Dent Assoc. 1992;58(3):217-221.

8. Kcohler B, Pettersson BM, Bratthall D. Streptococcus mutans in plaque and saliva and the development of caries. Scand J Dent Res. 1981;89(1):19-25.

9. Cury JA, Rebello MA, Del Bel Cury AA. In situ relationship between sucrose exposure and the composition of dental plaque. Caries Res. 1997;31(5):356-360

10.Cury JA, Rebelo MA, Del Bel Cury AA, Derbyshire MT, Tabchoury CP. Biochemical composition and cariogenicity of dental plaque formed in the presence of sucrose or glucose and fructose. Caries Res. 2000;34(6):491-497.

11. Nisengard RJ, Newman MG. Oral Microbiology and Immunology.2nd edn. Rio de Janeiro: Guanabara Koogan.1994.

12.World Medical Association Declaration of Helsinki, Ethical Principles for Medical Research, Involving Human Subjects. J Amer Medi Asso. 2013

13. Nobre dos Santos M, Melo dos Santos L, Francisco SB, Cury JA Relationship among dental plaque composition, daily sugar exposure and caries in the primary dentition. Caries Res.2002;36(5):347-352.

14.Pearce EI, Hancock EM, Gallagher IH. The effect of fluorhydroxyapatite in experimental human dental plaque on its $\mathrm{pH}$, acid production and soluble calcium, phosphate and fluoride levels following glucose challenge. Arch Oral Biol.1984;29(7):521-527.

15.Cury JA, Marques AS, Tabchoury CP, Del Bel Cury AA. Composition of dental plaque formed in the presence of sucrose and after its interruption. Braz Dent J.2003;14(3):147-152. doi.org/10.1590/ S0103-64402003000300001

16. Dubois M, Grilles KA, Hamilton JK, Rebers PA, Smith F. Colorimetric method for determination of sugars and related substances. Analyt Chem. 1956;28(3):350-356. doi: 10.1021/ac60111a017

17. Varma S, Banerjee A, Barlett D. An in vivo investigation of associations between saliva properties, caries prevalence and potential lesion activity in an adult UK population. J Dent. 2008;36(4):294-299. doi: 10.1016/j.jdent.2008.01.009

18. Gold O, Jordan H, Van-Houte J. A selective medium for S. mutans. Arch Oral Biol. 1973;18(11):1357-1364.

19. Beighton D, Russell R, Whiley R. A simple biochemical scheme for the differentiation of Streptococcus mutans and Streptococcus sobrinus. Caries Res. 1991;25(3):174-178.

20. McGhee J, Michalek S, Cassell G: Editors. Dental Microbiology Philadelphia: Harper and Row 1982.

21. Beighton D. A simplified procedure for estimating the level of Streptococcus mutans in the mouth. Br Dent J. 1986;160:329-330.

22. Kitasako Y, Moritsuka M, Foxton R M, Ikeda M, Tagami J, Nomura S. Simplified and quantitative saliva buffer capacity test using a handheld pH meter. AM J Dentist, 2005;18(3):147-150.

23. Moritsuka M, Kitasako Y, Burrow MF, Ikeda M, Tagami J. The $\mathrm{pH}$ change after $\mathrm{HCl}$ titration into resting and stimulated saliva for a buffering capacity test. Aust Dent J. 2006;51(2):170-174.

24.Teixeira HS, Kaulfuss SMO, Ribeiro JS, Pereira BR, Brancher JA, Camargo ES. Calcium, amylase, glucose, total protein concentrations, flow rate, $\mathrm{pH}$ and buffering capacity of saliva in patients undergoing orthodontic treatment with fixed appliances. Dent Press J Orthod. 2012;17(2):157-161. doi.org/10.1590/S2176-94512012000200026

25. Anderson P, Hector MP, Rampersad MA. Critical pH in resting and stimulated whole saliva in groups of children and adults. Int J Pediatr Dent. 2001;11(4):266-273. doi: 10.1046/j.1365-263X.2001.00293.x

26. Ericson T, Mäkinen KK. Saliva formation, composition and possible role. In:Thylstrup A, Fejerskov, O.Textbook of cariology. Copenhagen: Munksgaard. 1986;28-45.

27. Marsh PD. The significance of maintaining the stability of the natural microflora of the mouth. Br Dent J. 1991;171(6):174-177.

28. Bonetti1 G, Parenti S, Garulli G, Gatto M, Checchi L. Effect of fixed orthodontic appliances on salivary properties Progr in Orthod. 2013;14:13

29. Rosenbloom RG, Tinanoff N. Salivary Streptococcus mutans levels in patients before, during and after orthodontic treatment. Am J Orthod Dentofac Orthop. 1991;100(1):35-37. doi: 10.1016/08895406(91)70046-Y

30. Pandis N, Papaioannou W, Kontou E, Nakou M, Makou M, Eliades T. Salivary Streptococcus mutans levels in patients with conventional and self-ligating brackets. Eur J Orthod. 2010;32(1):94-99. doi: 10.1093/ejo/cjp033

31.Peros K, Mestrovic S, Milosevic SA, Slaj M. Salivary microbial and nonmicrobial parameters in children with fixed orthodontic appliances. Angle Orthod. 2011;81(5):901-906. doi: 10.2319/01211144.1

32. Li Y, Hu B, Liu Y, Zhang C, Wang S. The effects of fixed orthodontic appliances on saliva flow rate and saliva electrolyte concentrations. 
J Oral Rehabil. 2009;36(11):781-785. doi: 10.1111/j.13652842.2009.01993.x

33. Birkhed D, Heintze U. Salivary secretion rate, buffer capacity and $\mathrm{pH}$. In: Tenovuo JO. Human saliva: clinical chemistry and microbiology. Boca Raton: CRC Press. 1989;1:25-74.

34. Newbrun E. Preventing dental caries: current and prospective strategies. J Am Dent Assoc. 1992;123(5):68-73.

35. Dowd FJ. Saliva and dental caries. Dent Clin North Am. 1999;43(4):579597.

36.Edgar WM. Saliva: its secretion, composition and functions. Br Dent J. 1992;172(8):305-312.

37.EricsonT, Mäkinen KK. Saliva-formation, composition and possible role. In:Thylstrup A, Fejerskov, O.Textbook of cariology. Copenhagen: Munksgaard. 1986

38.Jenkins GN. The physiology and biochemistry of the mouth.4th ed. Oxford: Blackwell Scientific. 1978;284-359.

39. Lagerlof F, Oliveby A, Ekstrand J. Physiological factors influencing salivary clearance of sugar and fluoride. J Dent Res.1987;66(2):430435 .

40. Chang HG, Walsh LJ, Freer TJ. The effect of orthodontic treatment on salivary flow, $\mathrm{pH}$, buffer capacity, and levels of mutans streptococci and lactobacilli. Aust Orthod J.1999;15(4):229-263.

41. Kanaya T, Kaneko N, Amaike C, Fukushima M, Morita S, Miyazaki H, et al. A study on changes in caries risk and microbial flora with the placement of Edgewise appliance. Orthod Waves. 2007;66(2):27-32.

42. Ulukapi H, Koray F, Efes B. Monitoring the caries risk of orthodontic patients.Quintessence Int.1997;28(1):27-29

43. Laine M, Pienihakkinen K, Ojanotko-Harri A, Tenovuo J. Effects of low-dose oral contraceptives on female whole saliva. Arch Oral Biol.1991;36(7):549-552.

44. Bardow A, Moe D, Nyvad B, Nauntofte B. The buffer capacity and buffer systems of human whole saliva measured without loss of $\mathrm{CO2}$. Arch Oral Biol.2000;45(1):1-12.

45. Mattos-Graner RO, Smith DJ, King WF, Mayer MP. Water-insoluble glucan synthesis by mutans streptococcal strains correlates with caries incidence in 12 to 30 month old children. J Dent Res.2000;79(6):13711377.

46. Schwertner C, Moreira M, Faccini L \& Hashizume L. Biochemical composition of the saliva and dental biofilm of children with Down syndrome. Int J of Paed Dent. 2016;26(2):134-140. doi: 10.1111/ ipd.12168

47.Topaloglu-Ak A, Ertugrul F, Eden E, Ates M, Bulut H. Effect of orthodontic appliances on oral microbiota- 6 month follow-up. J Clin Pediatr Den. 2011;35(4):433-436.

48. Maret D, Marchal-Sixou C, Vergnes JN, Hamel O, Georgelin-Gurgel M, Van Der Sluis L, et al. Effect of fixed orthodontic appliances on salivary microbial parameters at 6 months: A controlled observational study. J Appl Oral Sci, 2014;22(1):38-43. doi.org/10.1590/1678775720130318 